\title{
W hat are the limits of the duty of care? The case of clinical genetics
}

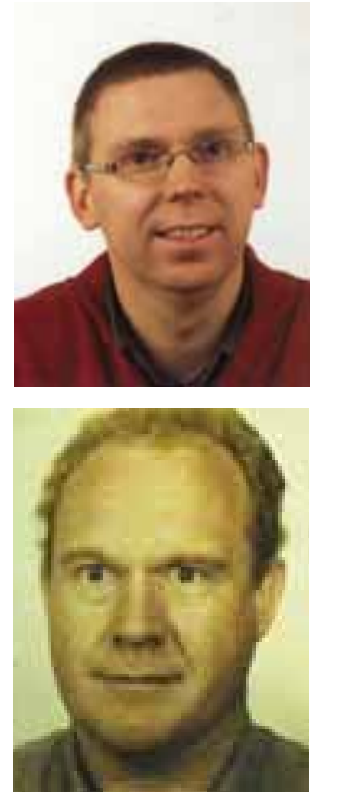

Pascal Bany' \& KrisDieidkx

${ }^{\dagger}$ Author for correspondence Katholieke U niversiteit Leuven, Centre for Biomedical Ethics and Law, Kapucijnenvoer 35/3, 3000 Leuven, Belgium Tel.: +32 16336951 ; Fax: +32 1633 6952; E-mail: Pascal.Borry@ med.kuleuven.be $f_{\text {medicine }}^{\text {fut }}$ iss
'Some evidence suggests that although parents are the best placed to inform their children of their genetic risk, some parents dec line to tell their children...'

Although the sharing of genetic information in families is strongly recommended, in some families communication regarding genetic risk is impeded. The desire to not cause anxiety or alarm, geographical distances, family conflicts, relational ruptures, adoption, generational gaps or complex family relations have been reported as issues that might make it more difficult to convey information to relatives [1]. The decision not to provide relevant genetic information to relatives might be based, on the one hand, on a deliberate choice of a person not to disclose results to relatives, as, for example, in the case of a 55-year-old woman who lies about her positive test result for BRCA with the aim "to protect her father from the guilt of having passed a mutation to an offspring" [2], or, on the other hand, based on the inability to deal with genetic risk information.

This question of the communication of genetic information will become increasingly relevant in the future as more genetic tests are developed and applied in various contexts. The further use of newborn screening using DNA mutation analysis is an important example of this evolution, because as well as identifying affected infants, it also reveals genetic carriers who are at risk of having children with the same disorder. To be a carrier mostly does not affect the health of the carrier, but could have consequences for the offspring.W hile in the past various newborn screening programs often did not report the identification of carriers detected $[3,101,102]$, recent recommendations on that issue $[4,5]$ seem to direct practice into the direction that parents should be told about this possibility before the test and that results should be given to the parents together with adequate counseling by a healthcare professional. The main concern addressed by neonatal screening programs regarding the identification of carriers and incidental results in the implementation of a universal screening program is no longer whether this information should be provided, but how. As newborn screening programs identify many more carriers than affected children, informing and counseling families of carriers identified by newborn screening is a major challenge.

Several empirical studies have shown that adults may encounter difficulties in assessing genetic risk $[6,7]$ and understanding the recessive patterns of inheritance [8,9]. Several studies have reported that parents may experience difficulties in retention of test results [10-12] and some studies have observed a low recall of residual risk after a negative test in the long term in spite of posttest counseling [11,13-16]. Although most understand the carrier status, almost all studies report that some individuals experience difficulties with the understanding of the carrier status. D ifferent studies [17] observed that some parents continue to have difficulties with the information regarding the carrier status in their children $[8,18]$. $M$ ischler et al. reported that a few families did not understand the meaning of being a carrier and seemed to believe that their carrier children might develop cystic fibrosis [19]. Another study found that 1 year after the carrier detection through neonatal screening, $15 \%$ of the families were not sure whether carrier status implied health difficulties [20].

It is more than likely that these parents will not be able to transmit accurate information to their offspring concerning their genetic risk. Children in these families might make the same erroneous assumptions and believe that they are, or will become, sick. Parents might initiate a socialization of the child into a sick role [8]. Some evidence suggests that although parents are the best placed to inform their children of their genetic risk, some parents decline to tell their children or family members [21-25], defer disclosure of genetic risk [21], encounter difficulties to tell their children or family members [26,27], or share it in a way that many family members are not fully aware of the risk of being a carrier [9].

This is clearly a very important responsibility for the parents of the minor. They have an important obligation to make a reasonable 
effort to understand the nature and implications of genetic information, to provide appropriate information to their children and to share the concerns and needs of their children [28]. They may assist their children in contacting genetic services for further information and genetic counseling. Various professional guidelines have underlined that parents, being inherently responsible for the welfare of their children, are also responsible for informing their children of their genetic risk [29]. An open discussion regarding familial genetic risk in an age-appropriate manner within the context of the family unit is recommended.

An important question here is whether parents are the only ones who carry a responsibility in this. Is there any moral or legal obligation for health professionals (geneticists or primary-care physicians) to recontact the family, years after the carrier status was identified, in order to ascertain that the genetic information was not forgotten and that information regarding carrier status was correctly communicated to the children? Should this be integrated in the task of a physician's continuing duty of care, compared with the duty of a physician "to monitor a patient's condition over a prolonged period of time", which may include "the obligation to advise of any developments in management and treatment that would prove of benefit or detriment to the patient" [30].

\footnotetext{
'Is there a ny moral or legal obligation for health professionals to recontact the fa mily, yea rs a fter the ca mier sta tus was identified, in order to ascerta in that the genetic information was not forgotten and that information regarding camier sta tus was correctly communic ated to the children?'
}

In the legal context, the failure to warn family members about their hereditary disease risks has resulted in a few malpractice suits against physicians in the USA [31]. These cases have raised concerns and reflections regarding the obligations and limits of physicians to respect the privacy of genetic information on the one hand, and the potential legal liability from a failure to notify atrisk relatives on the other. It is an open question whether the duty of care could be extended to include the duty of care to patients who were formerly the object of care, such as children who have a genetic risk for a specific disorder or have a risk to transmit a disorder to their offspring.
Various arguments are made against such a responsibility from clinical geneticists. First, organizing such a "perpetual duty of care" leads to "burdensome requirements for the storage and retrieval of information and to the diversion of funds for case review and management that may be better spent in other areas" [32]. Second, normally physicians make a distinction between patients who need follow-up care and those who do not. Patients who are discharged from care know that they have the responsibility to recontact the physicians for eventual follow-up. Third, it is debatable whether a clinical geneticist has the right to recontact (children from) former patients directly.

In a previous questionnaire study, we examined the attitudes of clinical geneticists regarding who is responsible for ensuring that a minor is informed about his genetic risk when it has been decided to postpone testing until adolescence or adulthood. The data provided here were not reported in any of the publications [33-35] that described this study. In total, 317 clinical institutes in the $27 \mathrm{EU}$ member states were contacted with the aim to receive one questionnaire back from every institute. of the 317 institutes we contacted, 36 were excluded because they were only providing laboratory services, prenatal diagnosis, had finished their activities or answered for two institutes. Of the remaining 281 institutes, 177 respondents returned a completed questionnaire, corresponding to a response rate of $63 \%$ (177 out of 281).

$\mathrm{O} n$ the question: "If a carrier test is delayed until adulthood, who is responsible for ensuring that the minor is informed about his genetic risk later in life?', most respondents considered this only $(27 \% ; 47$ out of 177$)$ or mainly $(41 \%$; 73 out of 177 ) the responsibility of the parents. A total of $29 \%$ (52 out of 177) considered this a shared responsibility of the center for clinical genetics and the parents. A minority considered this mainly $(2 \% ; 2$ out of 177$)$ or only $(1 \%$; 1 out of 177) the responsibility of the center for clinical genetics.

On the question: 'If a presymptomatic or predictive genetic test is delayed until adulthood, who is responsible for ensuring that the minor is informed about his genetic risk later in life?', the same pattern comes back. Most respondents advanced that this is only (23\%; 39 out of 171$)$ or mainly $(43 \% ; 73$ out of 177$)$ the responsibility of the parents. A total of $32 \%$ (54 out of 171) considered this a shared responsibility of the center for clinical genetics and the parents. A few 
respondents held the opinion that this is mainly $(2 \% ; 4$ out of 171$)$ or only $(1 \% ; 1$ out of 171$)$ the responsibility of the center for clinical genetics.

'It is clear from our survey that most clinic al genetic ists considered the parents to have the most important responsibility in the communic ation of this genetic information.'

Gender and age did not influence the responses. H owever, geography showed significant difference for both questions. Respondents from southern and eastern European countries were significantly more willing to consider this information duty a shared responsibility of the center for clinical genetics and the parents, either in the case of a carrier test $(z=-3.4742$; $p=0.0005)$ or a predictive genetic test $(z=-3.6932 ; p=0.0002)$.

It is clear from our survey that most clinical geneticists considered the parents to have the most important responsibility in the communication of this genetic information. 0 ur findings are similar to another study, which showed that genetic counsel ors prioritize the patient's responsibility over other concerns. "While genetic counselors in this study did acknowledge a responsibility to at-risk relatives, they viewed the act of disclosing without consent as outside their responsibility"[36]. Similarly, although clinical geneticists consider it of utmost importance that children will be informed correctly regarding their genetic risk, most of them consider this mainly the responsibility of the parents.

We also consider that the parents have a clear responsibility towards their children in this communicative role. H owever, we would like to stress the supportive role of clinical genetic services and the healthcare system in this communication process. First, strategies should be developed to help families communicate across the generations this kind of sensitive genetic information. We cannot leave parents alone in this process, but we should provide them with tools with which to address the important questions of what to tell and how to tell it (e.g., the communication skills-building intervention [37]). Second, the clinical geneticists, as part of this responsibility, should provide a written summary of their consultation with the children and should adequately counsel the parents of the child. Third, the primary-care physicians are expected to know the family and to be alert to potential threats and opportunities that could affect the health of family members. As a consequence, primary-care physicians are much better placed than clinical geneticists to keep in mind the genetic risk that a child might carry and refer them to the clinical genetic services when older. Finally, we should allow clinical genetic services to recontact the families. It should be possible to obtain permission for future contacts, for example at an initial consultation. This, of course, brings administrative and logistical challenges, as well as substantial costsfor maintaining a database that provides the ability to identify appropriate individuals for follow-up and recontact. O rganizing a system where people have to opt in for being recontacted later might be a useful tool, but is only possible if clinical genetic services have enough resources to organize this.

Financial \& competing interests disclosure The research for this article was supported by the Eurogentest Network of Excellence of the EU, FP6-512148. The authors have no other relevant affiliations or financial involvement with any organization or entity with a financial interest in or financial conflict with the subject matter or materials discussed in the manuscript apart from those disclosed.

No writing assistance was utilized in the production of this manuscript.
Bibliography

1. Clarke A, Richards M, Kerzin-Storrar L et al.: Genetic professionals' reports of nondisclosure of genetic risk information within families. Eur. J. H um. Genet. 13(5), 556-562 (2005).

2. Loud JT, Weissman NE, Peters JA et al.: $D$ eliberate deceit of family members: a challenge to providers of clinical genetics services. J. Clin. O ncol. 24(10), 1643-1646 (2006).

3. Green N S, D olan SM, M urray TH : $N$ ewborn screening: complexities in universal genetic testing. Am. J. Public $H$ ealth 96(11), 1955-1959 (2006).
4. UK N ewborn Screening Programme Centre: N ewborn Blood Spot Screening in the U K. Policies and Standards. N ewborn Screening Programme Centre, London, UK (2005).

5. Health Resources and Services Administration: N ewborn Screening: Toward a U niform Screening Panel and System. $H$ ealth Resources and Services Administration, M D , USA (2005).

6. Fanos JH : D evelopmental tasks of childhood and adolescence: implications for genetic testing. Am. J. M ed. G enet. 71(1), 22-28 (1997).
7. D enayer $L$, Welkenhuysen $M$, Evers-Kiebooms G, C assiman JJ, van den Berghe H : Risk perception after CF carrier testing and impact of the test result on reproductive decision making. Am. J. M ed. Genet. 69(4), 422-428 (1997).

8. Fanos JH, Johnson JP: Perception of carrier status by cystic fibrosis siblings. Am. J. H um. Genet. 57(2), 431-438 (1995).

9. D enayer $L$, de Boeck K, Evers-Kiebooms G, van den Berghe $\mathrm{H}$ : The transfer of information about genetic transmission to brothers and sisters of parents with a CF-child. Birth D efects 0 rig. Artic. Ser. 28(1), 149-158 (1992). 
10. Axworthy D, Brock DJ, Bobrow M, $M$ arteau T M : Psychological impact of population-based carrier testing for cystic fibrosis: 3-year follow-up. UK Cystic Fibrosis Follow-Up Study G roup. Lancet 347(9013), 1443-1446 (1996).

11. Bekker $H$, M odell M , D enniss $G$ et al.: U ptake of cystic fibrosis testing in primary care: supply push or demand pull? BM J 306(6892), 1584-1586 (1993).

12. Bekker $H, D$ enniss $G, M$ odell $M$, Bobrow M, M arteau T: The impact of population based screening for carriers of cystic fibrosis. J. M ed. Genet. 31(5), 364-368 (1994).

13. Watson EK, M ayall E, ChappleJ et al.: Screening for carriers of cystic fibrosis through primary health care services. BM J 303(6801), 504-507 (1991).

14. Mennie M E, Gilfillan $A$, Compton $M$ et al.: Prenatal screening for cystic fibrosis. Lancet 340(8813), 214-216 (1992).

15. Callanan N P, Cheuvront BJ, Sorenson JR: $\mathrm{CF}$ carrier testing in a high risk population: anxiety, risk perceptions, and reproductive plans of carrier by "non-carrier" couples. Genet. M ed. 1(7), 323-327 (1999).

16. M arteau TM, M ichieS, M iedzybrodzka ZH , Allanson A: Incorrect recall of residual risk three years after carrier screening for cystic fibrosis: a comparison of two-step and couple screening. Am. J. O bstet. Gynecol. 181(1), 165-169 (1999).

17. Fanos $\mathrm{J}, \mathrm{M}$ ackintosh $\mathrm{M} A$ : $\mathrm{N}$ ever again joy without sorrow: the effect on parents of a child with ataxia-telangiectasia. Am. J. M ed. Genet. 87(5), 413-419 (1999).

18. Fanos $J \mathrm{H}, \mathrm{N}$ ickerson $\mathrm{BG}$ : Long-term effects of sibling death during adolescence. J. Adolesc. Res. 6, 70-82 (1991).

19. M ischler $E H$, Wilfond $B S$, Fost $N$ et al.: Cystic fibrosis newborn screening: impact on reproductive behavior and implications for genetic counseling. Pediatrics 102(1), 44-52 (1998).
20. Ciske D J, H aavisto A, Laxova A, Rock LZ, Farrell PM : $G$ enetic counseling and neonatal screening for cystic fibrosis: an assessment of the communication process. Pediatrics 107(4), 699-705 (2001).

21. Forrest K, Simpson SA, W ilson BJ et al.: To tell or not to tell: barriers and facilitators in family communication about genetic risk. Clin. Genet. 64(4), 317-326 (2003).

22. Varekamp I, Suurmeijer TP, Brocker-Vriends AH et al.: Carrier testing and prenatal diagnosis for hemophilia: experiences and attitudes of 549 potential and obligate carriers. Am. J. M ed. Genet. 37(1), 147-154 (1990).

23. Varekamp I, Suurmeijer T, Brocker-VriendsA, Rosendaal FR: H emophilia and the use of genetic counseling and carrier testing within family networks. Birth $D$ efects 0 rig. Artic. Ser. 28(1), 139-148 (1992).

24. Varekamp I, Suurmeijer TP, Rosendaal FR, Brocker-Vriends AH : The use of preventive health care services: carrier testing for the genetic disorder haemophilia. Soc. Sci. M ed. 37(5), 639-648 (1993).

25. Sorenson JR, Jennings- $G$ rant $T, N$ ewman J: Communication about carrier testing within hemophilia A families. Am. J. M ed. Genet. $119 C$ (1), 3-10 (2003).

26. Fanos JH , Johnson JP: Barriers to carrier testing for adult cystic fibrosis sibs: the importance of not knowing. Am. J. M ed. Genet. 59(1), 85-91 (1995).

27. Duster $\mathrm{T}$ : $\mathrm{T}$ he social consequences of genetic disclosure. In: Behavioral Genetics The Clash of Culture and Biology. Carson RA, Rothstein M A (Eds). Johns H opkins University Press, London, UK, 172-188 (1999).

28. Sharpe N F: The duty to recontact: benefit and harm. Am. J. H um. Genet. 65(4), 1201-1204 (1999).

29. Borry P, Schotsmans P, Fryns JP, D ierickx K : Carrier testing in minors: a systematic review of guidelines and positions statements. Eur. J. H um. Genet. 14(2), 133-138 (2006).
30. Sharpe N F: Psychological aspects of genetic counseling: a legal perspective. Am. J. M ed. Genet. 50(3), 234-238 (1994).

31. O ffit $K$, G roeger $E$, Turner $S$, Wadsworth EA, Weiser M A: The "duty to warn" a patient's family members about hereditary disease risks. JAM A 292(12), 1469-1473 (2004).

32. Fitzpatrick JL, H ahn C, C osta T, $\mathrm{H}$ uggins $\mathrm{M} \mathrm{J}$ : T he duty to recontact: attitudes of genetics service providers. Am. J. H um. Genet. 64(3), 852-860 (1999).

33. Borry $\mathrm{P}, \mathrm{G}$ offin $\mathrm{T}, \mathrm{N}$ ys $\mathrm{H}$, D ierickx K: Attitudes regarding carrier testing in incompetent children. A survey of European clinical geneticists. Eur. J. H um. Genet. 15(12), 1211-1217 (2007).

34. Borry P, Stultiens L, G offin T, Nys H, Dierickx K: $M$ inors and informed consent in carrier testing. J. M ed. Ethics (2007) (In Press).

35. Borry P, G offin T, N ys H, D ierickx K: Attitudes regarding predictive genetic testing in minors. a survey of European clinical geneticists. Am. J. M ed. Genet. C Semin. M ed. Genet. 148C (1), 78-83 (2008).

36. Dugan $R B$, Wiesner $G L$, Juengst $E T$, $O$ 'Riordan M , M atthews AL, Robin N H : $D$ uty to warn at-risk relatives for genetic disease: genetic counselors' clinical experience. Am. J. M ed. Genet. C Semin. M ed. Genet. 119(1), 27-34 (2003).

37. Daly M B, Barsevick A, M iller SM et al.: Communicating genetic test results to the family: a six-step, skills-building strategy. Fam. Community Health 24(3), 13-26 (2001).

\section{Websites}

101. American M edical Association: Testing children for genetic status. www.ama-assn.org/

102. German Society of $\mathrm{H}$ uman $\mathrm{G}$ enetics. Statement on genetic diagnosis in children and adolescents. www.gfhev.de/en/gfh/ 